\title{
On the sedimentological character of Alpine basal ice facies
}

\author{
BRYN HUBBARD, \\ Centre for Glaciology, Institute of Earth Studies, The University of Wales, Aberystwyth, Dyfed Sr23 3DB, Wales \\ MARTIN SHARP, \\ Department of Geography, University of Alberta, Edmonton, Alberta T6G 2H4, Canada \\ WENDY J. LAWSON \\ Department of Geography, University of Canterbury, Private Bag 4800, Christchurch, New Zealand
}

\begin{abstract}
Seven basal ice facies have been defined on the basis of research at eleven glaciers in the western Alps. The concentration and texture of the debris incorporated in these facies are described. Grain-size distributions are characterised in terms of their: (i) mean size and dispersion, (ii) component Gaussian modes, and (iii) self-similarity.

Firnified glacier ice contains low concentrations $\left(\approx 0.2 \mathrm{~g} \mathrm{l}^{-1}\right)$ of well-sorted and predominantly fine-grained debris that is not self-similar over the range of particle diameters assessed. In contrast, basal ice contains relatively high concentrations $\approx 4$ $4000 \mathrm{~g} \mathrm{l}^{-1}$ by facies) of polymodal (by size fraction against weight) debris, the texture of which is consistent with incorporation at the glacier bed. Analysis by grain-size against number of particles suggests that these basal facies debris textures are also self-similar. This apparent contradiction may be explained by the insensitivity of the assessment of self-similarity to variations in mass distribution. Comparison of typical size-weight with size-number distributions indicates that neither visual nor statistical assessment of the latter may be sufficiently rigorous to identify self-similarity.

Apparent fractal dimensions may indicate the relative importance of fines in a debris distribution. Subglacially derived basal facies debris has a mean fractal dimension of 2.74. This value suggests an excess of fines relative to a self-similar distribution of cubes, which has a fractal dimension of 2.58. Subglacial sediments sampled from the forefield of Skalafellsjökull, Iceland, have fractal dimensions of 2.91 (A-horizon) and 2.81 (B-horizon). Debris from the A-horizon, which is interpreted as having been pervasively deformed, both most closely approaches self-similarity and has the highest fractal dimension of any of the sample groups analyzed.
\end{abstract}

\section{INTRODUCTION}

Lawson (1979) first presented a facies-based classification of ice forms at Matanuska Glacier, Alaska. Although this taxonomy has been widely adopted in studies of sub-polar glaciers (e.g. Knight, 1994), no such systematic reporting of facies characteristics has been made for the relatively thin basal ice sequences that characterise Alpine glaciers. Such an approach, however, is desirable since facies formed by specific processes may be used as a proxy for subglacial conditions at other glaciers where they are observed. In addition, variations in facies sedimentology may have important consequences for rates and patterns of basal deformation (see Hubbard and Sharp, 1989) and subglacial abrasion (e.g. Hallet, 1981). Characteristic facies sedimentologies may also be translated into distinctive till styles. Accurate specification of the concentration and texture of the debris entrained within
Alpine basal ice facies may therefore inform our understanding of the motion, erosion and deposition of such glaciers.

In this paper we describe the sedimentologies of seven basal ice facies that have been identified on the basis of research at eleven predominantly temperate-based, Alpine glaciers (for locations see Hubbard and Sharp, 1995). These sedimentologies are compared with those of other glacial and proglacial sediments.

\section{BASAL ICE FACIES SEDIMENTOLOGY - AN INTERPRETATIVE FRAMEWORK}

Most basal ice is easily identified by its high debris content relative to that of the cleaner glacier ice that overlies it. However, the disposition, concentration and texture of the debris entrained within basal ice may vary 
substantially. Each of these characteristics may be interpreted in terms of specific modes or environments of ice formation.

\section{Debris disposition}

Debris may be incorporated into basal ice either as layers or dispersed throughout the ice mass. The seasonal migration of a freezing front into subglacial sediments (Weertman, 1961) and the entrainment of debris only over certain zones of the glacier bed (Boulton, 1970) may result in a basal ice sequence that is foliated at a scale of decimetres to metres. At a smaller scale, Weertman regelation (Weertman, 1964) results in folia that may be sub-millimetre-thick (Kamb and LaChapelle, 1964; Hubbard and Sharp, 1993). In contrast, the formation of basal ice containing dispersed debris suggests incorporation that is temporally continuous. Such ice types may reflect the operation of continuous net basal adfreezing or the incorporation of fines from the glacier bed via the intergranular vein system (Knight and Knight, 1994).

The disposition of basal debris may change subsequent to initial incorporation: gravity and basal melting may cause clast migration towards the basal interface (e.g. Röthlisberger, 1968); recumbent folding may repeat and thicken basal ice layers (e.g. Hudleston, 1976); continuous simple shear close to the glacier bed may rotate ice structures such that they progressively approach parallelism with ice flow (Hooke and Hudleston, 1978); and intense and variable deformation close to the glacier bed may disperse and thicken basal ice layers, disrupting its foliation Sugden and others, 1987; Hubbard and Sharp, $1995)$.

\section{Debris concentration}

Variations in the concentration of debris incorporated in basal ice may reflect a number of controls, including:

The nalure of the substrate. In general, ice formed over unconsolidated sediments will be characterised by higher debris concentrations than ice formed over bedrock (e.g. Boulton, 1970).

The availability of water at the basal interface. Basal ice formation may be restricted by water availability above permeable substrates (Knight, 1988).

The rate of basal ice formation. Laboratory freezing experiments demonstrate that clasts may be rejected more effectively from freezing fronts at lower freezing speeds (Corte, 1962).

The accumulation of debris at the basal interface. Debris-rich basal ice may be recycled during multiple meltingrefreezing events over a hard glacier bed Hubbard and Sharp, 1993). During each event, the sediment already incorporated in the ice is supplemented by that eroded locally. Net basal melting also causes this debris to drift towards the ice/bedrock interface. Thus, in general, the longer the up-glacier flowline and the greater the integral of the rate of net basal melting, the greater the net debris concentration within basal ice layers.

\section{Debris texture}

Subglacial sediments are largely produced by, and/or subject to, erosion at the glacier bed. The frequently polymodal texture of such sediments is therefore explained by the operation of different subglacial erosion processes (Boulton, 1978; Haldorsen, 1981). Once produced, however, the texture of subglacial sediments may evolve further as they deform at the glacier bed. Recent research has focused on the self-similarity of subglacial sediment textures (Fischer, 1995; Hooke and Iverson, 1995). According to this hypothesis, sediments that deform by the fracture of clast-to-clast bridges develop grain-size distributions that provide the maximum support for all clasts. Such a distribution is selfsimilar (or fractal) and obeys the relation

$$
N_{d}=N_{0}\left(d / d_{0}\right)^{-m}
$$

(Hooke and Iverson, 1995), where $N_{d}$ is the number of particles of size $d, N_{0}$ is the number of particles of reference diameter $d_{0}$, and $m$ is the fractal dimension, given by the negative slope of a double logarithmic plot of number of particles against particle diameter. The value of $m$ therefore reflects the ratio of smaller to larger particles over the size range analyzed. A self-similar distribution of tessellating cubes has a fractal dimension of 2.58 Sammis and others, 1987).

The texture of debris incorporated within basal ice may, however, deviate from that of the subglacial sediment supply, since clasts may be preferentially incorporated or rejected at the freezing front during basal ice formation (Corte, 1962; Hubbard, 1991) and clasts may fracture during transport within the basal ice (Slatt and Eyles, 1981).

\section{METHODS}

Blocks of basal ice were recovered from subglacial and icemarginal locations, washed down to remove surface debris and allowed to melt in covered funnels lined with (Whatman 54) filter paper. Debris textures were determined for over 150 samples at $1 \phi$ intervals, from 5 to $3 \phi$ by dry sieving and from 3 to $9 \phi$ by laser granulometry. Results are presented in three ways:

(1) As the mean grain-size $\phi$ and dispersion (standard deviation) of the weight fractions comprising each sample. These are averaged by facies and plotted against each other (Fig. 1).

(2) As plots of size $(\phi)$ against weight (percentage) (Fig. 2 ). These are analyzed quantitatively by Gaussian component analysis (GCA) Sheridan and others, 1987; Sharp and others, 1994) which tunes the modes and standard deviations of component Gaussian sub- populations to fit the parent sample distributions (Table 1).

(3) As double logarithmic plots of particle diameter $(d)$ against number of particles $N_{d}$ over the five orders of magnitude range of debris sizes sampled $(0.003-23 \mathrm{~mm})$. Samples that do not include all these size fractions (invariably due to an absence of coarser clasts) are 
Hubbard and others: Sedimentologies of Alpine basal ice facies

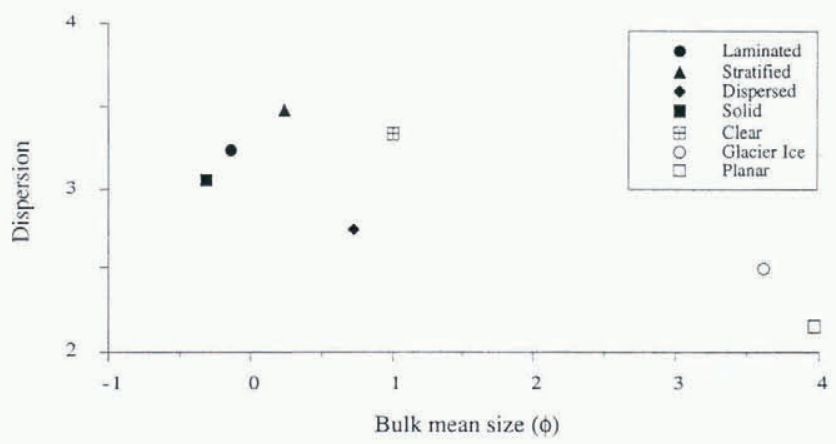

Fig. 1. Mean debris grain-size plotted against dispersion by facies.

considered to be not fractal. Debris self-similarity is indicated by the linearity of these distributions and is assessed in terms of the correlation coefficient of the diameter-number plots; the higher the correlation
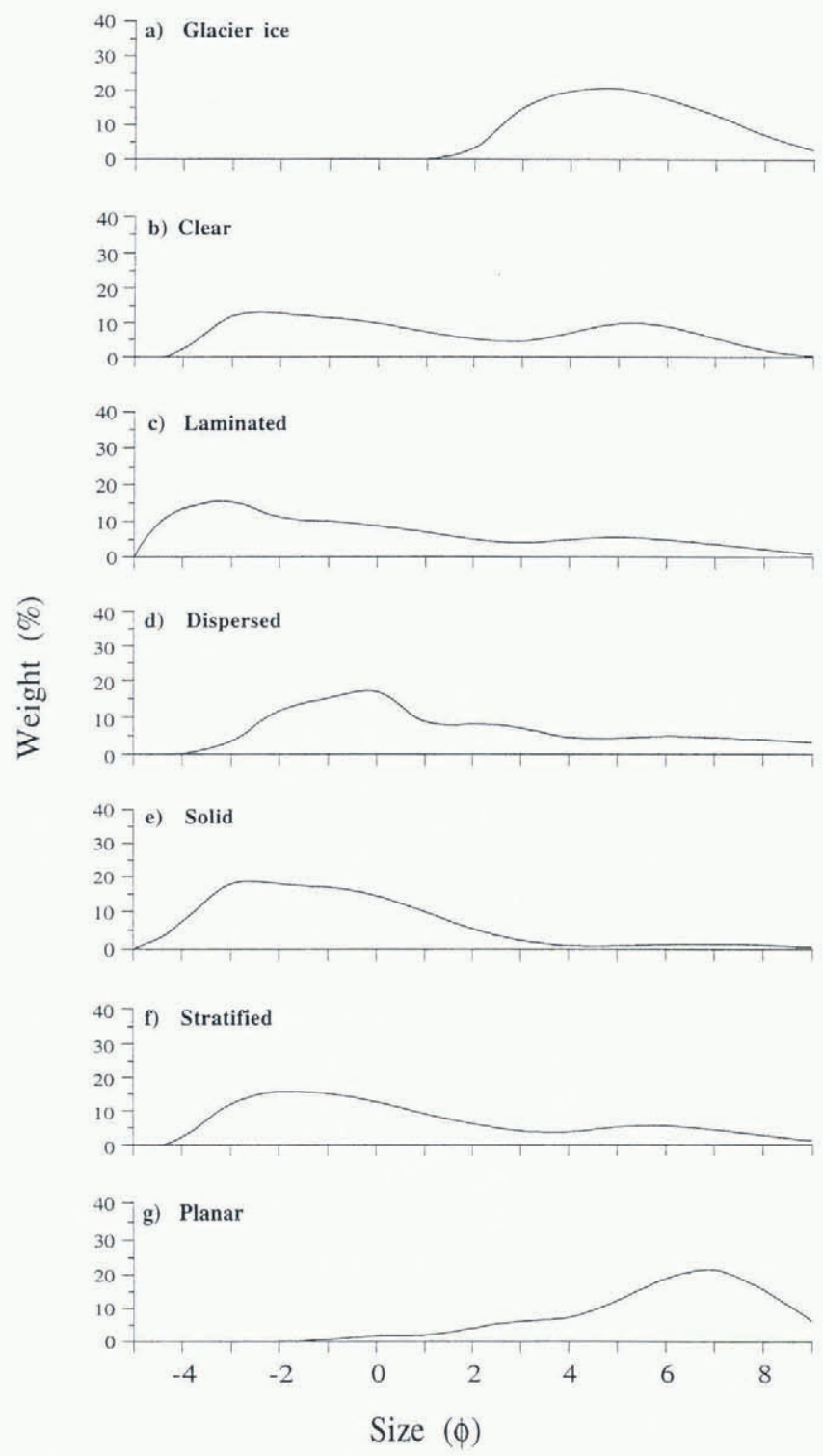

Fig. 2. Typical size-weight distributions of debris incorporated within: (a) glacier ice (Tsanfleuron), (b) clear-faciè ice (Ferpècle), (c) laminated-facies ice (Ferpècle), (d) dispersed-facies ice (Tsanfleuron), (e) solid-facies ice (Haut Arolla), (f) stratified-facies ice (Tsijiore. Nouve) and (g) planar-facies ice (Haut Arolla).
Table 1. Gaussian component analysis summary data for selected debris samples referred to in text

\begin{tabular}{|c|c|c|c|c|}
\hline \multirow[t]{3}{*}{ Facies (glacier) } & \multicolumn{4}{|c|}{ Mode } \\
\hline & 1 & 2 & 3 & 4 \\
\hline & \multicolumn{4}{|c|}{ Mean $\phi$ size (\% explained $)$} \\
\hline $\begin{array}{l}\text { Glacier ice } \\
\text { (Haut Arolla) }\end{array}$ & $-0.4(57)$ & $5.7(45)$ & & \\
\hline $\begin{array}{l}\text { Clear } \\
\text { Ferpècle) }\end{array}$ & $-3.2(13)$ & $-0.8(51)$ & $4.8(38)$ & \\
\hline $\begin{array}{c}\text { Interfacial layered } \\
\text { Tsanfleuron }\end{array}$ & $-5.1(63)$ & $-4.4(14)$ & $3.4(5)$ & \\
\hline $\begin{array}{l}\text { Laminated } \\
\text { (Bossons) }\end{array}$ & $-2.5(12)$ & $1.6(46)$ & $6.0(44)$ & \\
\hline $\begin{array}{l}\text { Laminated } \\
\text { (Turtmann) }\end{array}$ & $-2.5(82)$ & $2.4(5)$ & $4.8(10)$ & \\
\hline $\begin{array}{l}\text { Dispersed } \\
\text { (Tsanfleuron) }\end{array}$ & $1.6(72)$ & $4.7(17)$ & $6.8(10)$ & \\
\hline $\begin{array}{l}\text { Dispersed } \\
\text { (Tsanfleuron) }\end{array}$ & $-3.7(46)$ & $-1.1(40)$ & $1.6(8)$ & 5.06 \\
\hline $\begin{array}{l}\text { Solid } \\
\text { (Haut Arolla) }\end{array}$ & $-2.04(94)$ & $5.63(7)$ & & \\
\hline $\begin{array}{l}\text { Subglacial sediments } \\
\text { Haut Arolla }\end{array}$ & $-2.12(93)$ & $5.99(4)$ & & \\
\hline $\begin{array}{l}\text { Stratified } \\
\text { (Tsijiore Nouve) }\end{array}$ & $-1.29(65)$ & $5.73(36$ & & \\
\hline $\begin{array}{l}\text { Planar } \\
\text { (Haut Arolla) }\end{array}$ & $2.6(18)$ & $6.3(80)$ & & \\
\hline
\end{tabular}

coefficient the closer the sample approximates selfsimilarity. Where a tendency to self-similarity is demonstrated, the negative slope of the diameter number plot indicates a sample's fractal dimension (above). Correlation-coefficient and slope statistics for individual debris samples are averaged by facies and plotted against each other as a summary of this information (Fig. 3).

\section{BASAL ICE FACIES IN THE WESTERN ALPS}

Seven basal ice facies have been identified on the basis of being both visually distinctive and observed repeatedly at one or more of the glaciers studied (Table 2). The definitions presented below relate principally to the stratigraphy and sedimentology of these facies. Unless otherwise stated, debris textures are interpreted in terms of size - weight distributions. Genetic interpretations of the isotopic composition, ionic composition and crystallography of these facies are presented elsewhere Hubbard, 1992; Hubbard and Sharp, 1995).

\section{(i) Clear facies}

Clear-facies ice is composed of decimetres to metres of massive, debris-poor ice that is devoid of internal layering. This facies contains occasional clouds of flattened bubbles and small debris agglomerations that may give the ice a translucent appearance. This facies is present at the bases of all the glaciers studied, and often forms the matrix within which layers and pods of other ice facies are included.

The mean concentration of clear-facies debris is 
Table 2. Summary of the stratigraphies and sedimentologies of the basal ice facies identified (firnified glacier ice is presented for comparison)

\begin{tabular}{|c|c|c|c|c|c|c|}
\hline \multirow[t]{2}{*}{ Facies/Ice type } & \multirow[t]{2}{*}{ Typical thickness } & \multirow[t]{2}{*}{ Physical character } & \multicolumn{2}{|c|}{ Debris concentration } & \multicolumn{2}{|c|}{ Debris lexture } \\
\hline & & & $\begin{array}{l}\text { Mean } \\
\mathrm{g} \mathrm{l}^{-1}\end{array}$ & $\begin{array}{c}\sigma \\
g l^{-1}\end{array}$ & $\begin{array}{c}\text { Mean } \\
\phi\end{array}$ & $\begin{array}{l}\sigma \\
\phi\end{array}$ \\
\hline Glacier ice & to $10^{2}$ & $\begin{array}{l}\text { Bubble-foliated at } 10^{-2} \text { to } 10^{-1} \mathrm{~m} \text {. Contains } \\
\text { dispersed uni-/bimodal debris. }\end{array}$ & 0.2 & 0.1 & 3.6 & - \\
\hline Clear & $10^{-1}$ to $10^{0}$ & $\begin{array}{l}\text { Translucent layers containing dispersed } \\
\text { polymodal debris nodules and pockets of } \\
\text { flattened gas bubbles }\end{array}$ & 4.1 & 4.9 & 1.0 & 0.4 \\
\hline Laminated & $10^{-2}$ to $10^{-1}$ & $\begin{array}{l}\text { Closely-spaced }\left(10^{-3} \mathrm{~m}\right) \text { polymodal debris } \\
\text { laminae, separated by clean, bubble-free } \\
\text { ice }\end{array}$ & 262 & 236 & -0.1 & 1.3 \\
\hline $\begin{array}{c}\text { Interfacial } \\
\text { layered }\end{array}$ & $10^{-2}$ to $10^{-1}$ & $\begin{array}{l}\text { Ice layers on bedrock floors; bed-parallel } \\
\text { layering defined by planar crystal boundaries }\end{array}$ & - & - & - & - \\
\hline continuous & $10^{-1}$ & $\begin{array}{l}\text { Ice units enclosed within bedrock hollows; } \\
\text { sub-vertical bubble lineations }\end{array}$ & - & - & - & - \\
\hline Dispersed & $10^{-1}$ & $\begin{array}{l}\text { Bubble-free ice containing dispersed poly- } \\
\text { modal debris; crudely layered by concen- } \\
\text { tration at } 10^{2} \mathrm{~m}\end{array}$ & 47 & 29 & 0.7 & 1.8 \\
\hline Solid & $10^{-2}$ to $10^{-1}$ & $\begin{array}{l}\text { Clast-supported units of highly variable } \\
\text { frozen debris }\end{array}$ & 4410 & 8910 & -0.3 & 1.4 \\
\hline Stratified & $10^{1}$ & $\begin{array}{l}\text { Intercalated layers }\left(10^{-1} \text { to } 10^{\circ} \mathrm{m}\right) \text { of } \\
\text { polymodal debris-rich ice and glacier ice }\end{array}$ & 45 & 43 & 0.2 & 0.9 \\
\hline Planar & $10^{-3}$ & $\begin{array}{l}\text { Thin planes of fine, unimodal debris; } \\
\text { frequently cutting across other ice folia }\end{array}$ & & - & 4.0 & 0.8 \\
\hline
\end{tabular}

$4.1 \mathrm{gl}^{-1}$ number of samples $(n)=3$ ). This debris is polymodal (Fig. 2) and has a mean grain-size of $1.0 \phi$ (Fig. 1). GCA best describes a typical size-weight distribution in terms of three modes, located at $-3.2 \phi$ (explaining $13 \%$ of the sample), $-0.8 \phi(51 \%)$ and $4.8 \phi$ $(38 \%)$ (Table 1). Particle-diameter-abundance plots indicate a mean fractal dimension of $2.73(R=-0.995)$ (Fig. 3).

\section{(ii) Laminated facies}

This facies is composed of debris laminae, each some

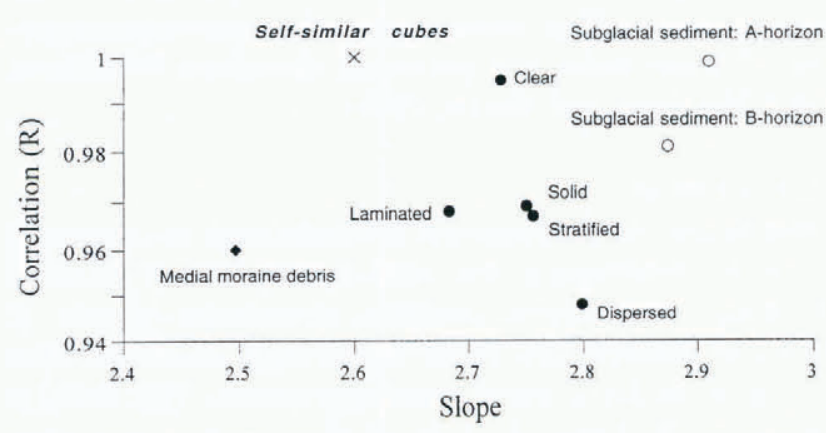

Fig. 3. Comparison of the slope and correlation coefficient of plots of particle diameler against abundance averaged by facies. tenths of a millimetre to a millimetre thick, that are generally bed-conformable, but which often pinch-out and merge laterally. Layers of laminated-facies ice somé centimetres to decimetres thick were observed in immediate contact with the glacier bed at four of the glaciers studied Bossons, Ferpècle, Gruben and Turtmann). Laminated-facies debris occurs in relatively high concentrations $\left(\right.$ mean $\left.=262 \mathrm{gl}^{-1} ; n=61\right)$, has a mean grain-size of $-0.1 \phi(n=46)$ and is commonly polymodal (Fig. 2). However, a high degree of textural variability was recorded between samples. For example, a composite sample of laminated-facies debris from Glacier des Bossons is dominated by silt-sized debris whilst a similar sample from Turtmanngletscher is almost devoid of debris finer than fine sand (Table 1). Particle-diameter abundance plots indicate a mean fractal dimension of $2.68(R=-0.968)$ (Fig. 3).

\section{(iii) Interfacial facies}

Interfacial-facies ice forms within basal cavities, where it may be deposited as layers on bedrock floors or as units enclosed within bedrock hollows. Each is defined as a subfacies, the former as interfacial layered sub-facies ice and the latter as interfacial continuous sub-facies ice.

Interfacial layered sub-facies ice is dominated by accordant, sub-horizontal crystal folia, each spaced some millimetres to centimetres apart. These layers, and the 
upper surface of the sub-facies, undulate with the largescale roughness of the underlying bedrock. The sub-facies is generally debris-free.

Interfacial continuous sub-facies ice is characterised by a horizontal upper surface and contains sub-vertical bubble lineations that are occasionally associated with fine debris. No debris samples were recovered from this sub-facies.

\section{(iv) Dispersed facies}

Dispersed-facies ice is present as a continuous layer some decimetres thick along the frontal margin of Glacier de Tsanfleuron. This facies is generally bubble-free and contains debris that is dispersed throughout the ice at a mean concentration of $47 \mathrm{gl}^{-1}(n=26)$, although a tendency towards crude concentration layering over centimetres was observed. This debris is generally coarse (mean size $=0.7 \phi ; n=14$; Fig. 1) but variable. GCA indicates that dispersed-facies debris may best be described by three or four modes, depending on the presence or absence of gravel-sized particles (Table 1). Particle-diameter-abundance plots indicate a mean fractal dimension of $2.80(R=-0.948)$ (Fig. 3).

\section{(v) Solid facies}

This facies is composed of clast-supported, frozen debris within which ice is predominantly interstitial and occasionally forms small lenses. Debris concentrations are correspondingly high (mean $=4410 \mathrm{gl}^{-1} ; n=20$ ). The facies is generally irregular in size and geometry, commonly occurring either as layers coating ice surfaces, irrespective of their orientation, or as pods interstratified with other facies. Both of these forms may be centimetres to metres thick, and included debris may be characterised by preserved sedimentary structures, frequently in the form of sorted layers. Solid-facies debris textures are highly variable, possibly reflecting a variety of potential debris sources. Particle-diameter-abundance plots indicate a mean fractal dimension of $2.75(R=-0.969)$ (Fig. 3).

\section{(vi) Stratified facies}

Stratified-facies ice consists of laterally extensive layers of debris-rich, bubble-free ice interstratified with layers of glacier ice. Both layers are decimetres to metres thick and the facies was observed to a total thickness of more than $10 \mathrm{~m}$ at two of the glaciers studied (Giétro and Tsijiore Nouve). The mean size of the debris included within the debris-rich layers is $0.2 \phi(n=22$; Fig. 1). GCA best describes this debris in terms of two modes that are similar in samples from both glaciers: one broad mode centred on $-1.3 \phi$ (explaining $65 \%$ of the sample) and a secondary mode at $5.7 \phi(36 \%)$ (Table 1). Particle-diameterabundance plots indicate a mean fractal dimension of $2.76(R=-0.967)$ (Fig. 3).

\section{(vii) Planar facies}

This facies is defined by discrete, planar surfaces that generally dip steeply and extend for some metres above the glacier bed, often cutting across bubble-foliated glacier ice. The planar facies was observed at all the glaciers studied and is defined by a thin layer of wellsorted, fine debris (mean grain size $=4.0 \phi ; n=6$ ) that may be bounded for some centimetres on either side by clean, bubble-free ice. GCA of planar-facies debris sampled from Haut Glacier d'Arolla indicates a bimodal composition, with a primary mode centred on $6.3 \phi$ (explaining $80 \%$ of the sample), and a secondary mode on $2.6 \phi(18 \%)$ (Table 2). Particle-size-weight plots indicate an absence of clasts coarser than $-1 \phi$ (Fig. 2). We therefore interpret this debris as being not self-similar over the range of grain-sizes assessed in the present study.

\section{DISCUSSION}

Basal facies debris is coarse-grained (with the exception of the planar facies) and occurs at concentrations of 4 $4000 \mathrm{~g} \mathrm{l}^{-1}$. These samples have a mean grain-size of $0.0 \phi$ $(n=110)$ and frequently contain a significant gravelsized $(<-2 \phi)$ fraction. In contrast, debris that is dispersed through the overlying glacier ice is fine-grained (mean grain-size $=3.5 \phi ; n=3$ ) and occurs in low concentrations $\left(\right.$ mean $=0.2 \mathrm{gl}^{-1} ; n=3$ ) (Table 1$)$. These characteristics reflect two fundamentally different debris supplies; wind-blown in the case of that present within the glacier ice, and subglacial incorporation in the case of that present in the basal ice layers.

Basal facies debris textures also differ from glacier-ice (and planar-facies) debris textures in that the latter are not self-similar over the range of grain-sizes analyzed. In contrast, basal facies debris textures are characterised by strong, inverse linear relationships between log particle diameter and $\log$ number of particles (Fig. 3). These relationships are described by high correlation coefficients: -0.995 for clear, -0.968 for laminated, -0.948 for dispersed, -0.967 for stratified, and -0.969 for solid facies debris. Such strongly linear (diameter-number) distributions have been interpreted as indicating self-similarity (e.g. Hooke and Iverson, 1995). However, these same basal facies debris samples are typically modal when plotted as grain-size vs weight distributions. A problem therefore arises with interpretation of such samples as selfsimilar since the grain-size-weight distribution of a selfsimilar sediment is exponential, not modal. These debris samples cannot therefore be truly self-similar. This apparent incongruity arises from the insensitivity of the method of establishing self-similarity the visual or statistical assessment of the linearity of plots of $\log$ particle diameter vs $\log$ number of particles) to variations in mass distribution. In order to investigate this insensitivity we compare size-weight plots with diameter-number plots for three samples: a (theoretical) self-similar distribution, an artificial bimodal distribution and an actual laminated-facies debris distribution (Fig. 4). These samples are characterised by distinctive sizeweight distributions, two of which are markedly modal (Fig. 4a). However, particle-diameter-number plots are characterised by high correlation coefficients for all three samples: -1.000 (by definition), -0.993 and -0.999 for the self-similar, bimodal and laminated-facies debris, respectively (Fig. 4b). These linear relationships and corresponding correlation coefficients are all indicative of selfsimilarity, yet only one of the samples is truly self-similar. This comparison therefore suggests that neither visual assessment of the linearity of diameter-number relationships (e.g. Fischer, 1995; Hooke and Iverson, 1995) nor a 


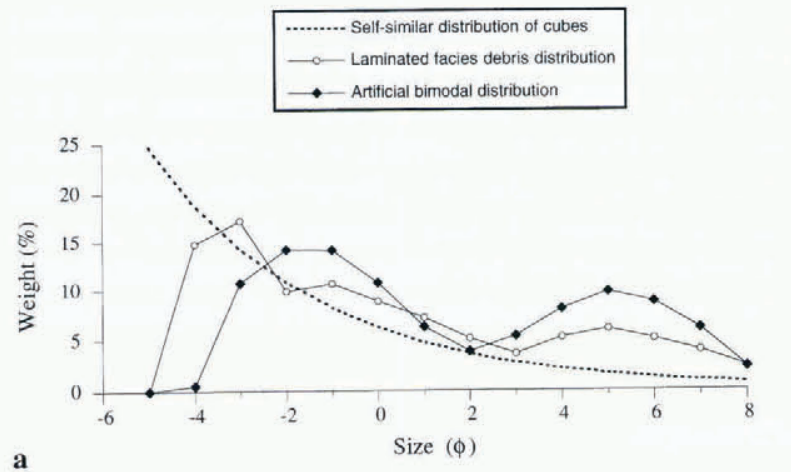

a

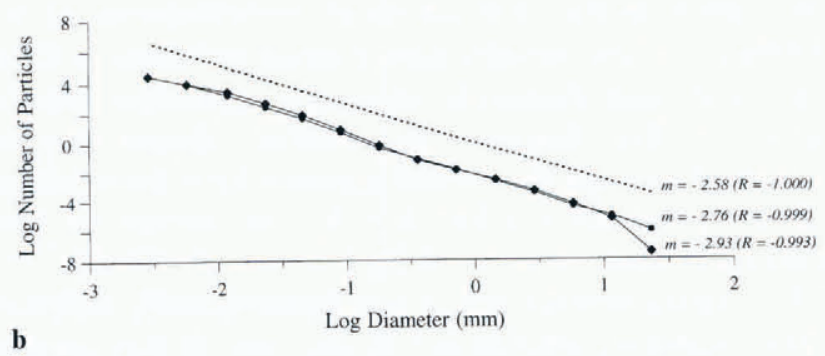

Fig. 4. Comparison of the mass distributions of three samples according to (a) grain-size vs weight and (b) grain diameter vs particle abundance.

correlation coefficient describing such a relationship that is as high as -0.999 may be sufficiently rigorous to establish the self-similarity of a debris distribution. In practice, therefore, there may be no simple way to distinguish a self-similar from a modal distribution. Instead, the correlation coefficient of the diameternumber slope may indicate the degree to which a sample approximates self-similarity.

Despite these problems of definition, sediment textures may be characterised by their fractal dimensions irrespective of whether they are strictly self-similar. In general, higher fractal dimensions indicate higher ratios of fine particles to coarse particles over the size ranges represented. High fractal dimensions have therefore been associated with intense and high-energy clast fracturing (e.g. Hartmann, 1969; Fujiwara and others, 1977). Recently, Fischer (1995) and Hooke and Iverson (1995) have extended this interpretation to subglacial sediments, arguing that fractal dimensions of $\approx 2.9$ may be indicative of deformation involving the fracture of clast-to-clast contacts.

Alpine basal facies debris textures are characterised by fractal dimensions of between 2.68 (laminated facies) and 2.80 (dispersed facies) (Fig. 3). These values suggest relatively high-energy comminution and an excess of fines relative to a self-similar distribution of tessellating cubes, which has a fractal dimension of 2.58 (Sammis and others, 1987). For comparison, debris sampled from a medial moraine at Glacier de Trient, Switzerland, and 24 proglacial till samples from Skalafellsjökull, Iceland, have also been analyzed. Eleven of the till samples were recovered from the deformed $\mathrm{A}$-horizon, and the remaining 13 from the underlying, consolidated Bhorizon (Sharp, 1982). The former group has a mean fractal dimension of $2.91(R=-0.999)$ and the latter one of $2.87(R=-0.981)$. These fractal dimensions are similar to those of the subglacial sediments analyzed from Storglaciären, Sweden (2.9; Hooke and Iverson, 1995), and Trapridge Glacier, Canada (2.95; Fischer, 1995). All four fractal dimensions are remarkably similar and relatively high compared with that of a self-similar distribution of cubes. The Skalafellsjökull till textures are therefore consistent with those hypothesised on the basis of active subglacial deformation. A subglacialsediment fractal dimension of $\approx 2.9$ is also higher than those of the basal facies debris identified in the present study, suggesting a general under-representation of fines in the latter. This may reflect a variety of processes, including fluvial removal of fines from the ice/substrate interface prior to incorporation; selective incorporation of coarser particles into newly formed ice at the freezing front (Hubbard, 1991); and diagenetic processes within the ice, such as Ostwald's ripening (Fairchild and others, 1993). In contrast, debris sampled from a medial moraine on the surface of Glacier de Trient has a fractal dimension of $2.50(R=-0.96)$, indicating (i) a relatively weak tendency towards self-similarity compared with both subglacial debris samples and the majority of basal facies debris samples, and (ii) an under-representation of fines relative to all other samples analyzed (Fig. 3). Both of these characteristics may reflect the "passive" transport path followed by such supraglacial debris (Boulton, 1978) relative to that transported at the glacier bed.

\section{SUMMARY}

Seven basal ice facies have been defined on the basis of research at eleven glaciers in the western Alps. The sedimentologies of these facies are summarised in Table 2, along with those of the debris entrained within the overlying glacier ice and that forming a supraglacial medial moraine.

Basal facies debris is readily distinguished from that incorporated in the overlying glacier ice: the former occurs in higher concentrations and is relatively coarse-grained. Basal facies debris size-weight distributions are also frequently modal, perhaps reflecting the influence of specific subglacial processes of erosion. However, particlediameter-number plots suggest that these textures also approximate self-similarity over the range of grain-sizes analyzed. Basal facies debris has a fractal dimension of 2.68-2.80, indicating an excess of fine particles relative to a self-similar distribution of tessellating cubes. This may reflect high-energy grain fracturing at the glacier bed, possibly by the deformation-induced comminution of subglacial sediments. Such sediments, sampled from the proglacial area of Skalafellsjökull, Iceland, closely approximate true self-similarity and have the highest fractal dimension $(\approx 2.9)$ of any of the sample groups included in the study. This fractal dimension is consistent with that of deformed subglacial sediments sampled from Storglaciären, Sweden, and Trapridge Glacier, Alaska. In contrast, debris sampled from a supraglacial medial moraine is characterised by the lowest fractal dimension (2.50) of any of the sample groups analyzed, reflecting the relative absence of fines from these passively transported sediments. 


\section{ACKNOWLEDGEMENTS}

Gratitude is extended to A. Hubbard, N. Spedding and M. Skidmore for assistance in the field. We thank P. Jansson and M. Lilliesköld for helpful comments on the manuscript. B.H. acknowledges receipt of a U.K. Natural Environment Research Council Studentship GT4/88/ GS/22).

\section{REFERENCES}

Boulton, G. S. 1970. On the origin and transport of englacial debris in Svalbard glaciers. J. Glaciol., 9 56), 213-229.

Boulton, G.S. 1978. Boulder shapes and grain size distributions as indicators of transport paths through a glacier and till genesis. Sedimentology. 25 6), $773-799$.

Corte, A.E. 1962. Vertical migration of particles in front of a moving freezing plane. J. Geoplyss. Res., 67 (3), 1085-1090.

Fairchild, I.J., L. Bradby and B. Spiro. 1993. Carbonate diagenesis in ice. Geolog), 21 10), $901-904$.

Fischer, U.H. 1995. Mechanical conditions beneath a surge-type glacier. Ph.D. thesis, University of British Columbia, Vancouver, Canada.

Fujiwara, A., G. Kamimoto and A. Tsukamoto. 1977. Destruction of basaltic bodies by high velocity impact. Icarus, 31, 277-288.

Haldorsen, S. 1981. Grain-size distribution of subglacial till and its relation to glacial crushing and abrasion. Boreas, 10 (1), 91-105.

Hallet, B. 1981. Glacial abrasion and sliding: their dependence on the debris concentration in basal ice. Ann. Glaciol., 2, 2328.

Hartmann, W.K. 1969. Terrestrial, lunar, and interplanetary rock fragmentation. Icarus, 10, 201-213.

Hooke, R. LeB. and P.J. Hudleston. 1978. Origin of foliation in glaciers. J. Glaciol., 20 83, 285-299.

Hooke, R. LeB, and N. R. Iverson. 1995. Grain-size distribution in deforming subglacial tills: role of grain fracture. Geology, 23 1), 57-60.

Hubbard, B. 1991. Freezing-rate effects on the physical characteristics of basal ice formed by net adficezing. 7. Glaciol., 37 127). $339-347$.

Hubbard, B. 1992. Basal ice facies and their formation in the western Alps. Ph.D. thesis. University of Cambridge, Cambridge, U.K.

Hubbard, B. and M. Sharp. 1989. Basal ice formation and deformation: a review. Progr. Phys. Geogr., 13 4), 529-558.
Hubbard, B. and M. Sharp. 1993. Weertman regelation, multiple refreczing events and the isotopic evolution of the basal ice layer. $\mathcal{J}$. Glaciol., 39 132). $275-291$.

Hubbard, B. and M. Sharp. 1995. Basal ice facies and their formation in the Western Alps. Aret. Alp. Res., 27 4), 301-310.

Hudleston. P.J. 1976. Recumbent folding in the base of the Barnes Ice Cap, Baffin Island, Northwest Territories, Canada. Geol. Soc. Am. Bull., 87 (2), 1684 1692.

Kamb, B. and E. LaChapelle. 1964. Direct observation of the mechanism of glacier sliding over bedrock. J. Glaciol., 5 38, 159-172.

Knight, P. G. 1988. The basal ice and debris sequence at the margin of an equatorial ice cap; El Cotopaxi, Ecuador. Geogr. Ann., 70A 1-2), $9-13$.

Knight, P. G. 1994. Two-facies interpretation of the basal layer of the Greenland ice sheet contributes to a unified model of basal ice formation. Geology, 2211 ), $971-974$.

Knight, P. G. and D. A. Knight. 1994. Correspondence Glacier sliding, regelation water flow and development of basal ice). \%. Glaciol., $40136) .600-601$.

Lawson, D. E. 1979. Sedimentological analysis of the western terminus region of the Matanuska Glacier, Mlaska. CRREL Rep. 79-9.

Röthlisberger, H. 1968. Erosive processes which are likely to accentuate or reduce the bottom relief of valley glaciers. In International Association of Hydrological Sciences Publication Vol. 79. General Assembly of Bern 1967-Snow and Ice), 87-97.

Sammis, C., G. King and R. Biegel. 1987. The kinematics of gouge deformation. Pure Appl. Geophss, 125 5). 777812.

Sharp, M. 1982. A comparison of the landforms and sedimentary sequences produced by surging and non-surging glaciers in Iccland. Ph.D. thesis, University of Aberdeen, Aberdeen, L.K.

Sharp, M.. J. Jouzel, B. Hubbard and W. Lawson. 1994. The character. structure and origin of the basal ice layer of a surge-type glacier. $\mathcal{F}$. Glaciol., $40135,327-340$.

Sheridan, M.F., K. H. Wohletz and J. Dehn. 1987. Discrimination of grain-size populations in pyroclastic deposits. Geology, 15 4), 367-370.

Slatt. R.M. and N. Eyles. 1981. Petrology of glacial sand: implications for the origin and mechanical durability of lithic fragments, Sedimentology, $282,171-183$.

Sugden, D. E. and 6 others. 1987. Evidence for two zones of debris entrainment bencath the Greenland ice sheet. Nature, 3286127 . $238-241$.

Weertman, J. 1961. Mechanism for the formation of inner moraines found near the edge of cold ice caps and ice sheets. 7. Glaciol., 3 (30), 965978.

Weertman. J. 1964. The theory of glacier sliding. J. Glaciol., 5 39), $287-303$. 